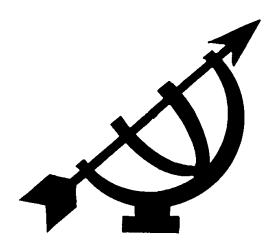

\title{
When "paradigms" differ: scientific communication between skepticism and hope in recent philosophy of science
}

\author{
R. Coletto \\ School of Philosophy \\ Potchefstroom Campus \\ North-West University \\ POTCHEFSTROOM \\ E-mail: Renato.Coletto@nwu.ac.za
}

\begin{abstract}
A new scientific truth does not triumph by convincing its opponents and making them see the light, but rather because its opponents eventually die.
\end{abstract}

(Max Planck, 1949:33-34.)

\begin{abstract}
When "paradigms" differ: scientific communication between skepticism and hope in recent philosophy of science

The first half of this article illustrates how contemporary humanist philosophy of science got caught up in a gradual loss of confidence concerning the possibility of sound communication among scholars holding on to different paradigms or presuppositions. The second half is dedicated to the responses provided by a Christian school of philosophy to the bleak possibility of a communication crisis. The resources deployed by the reformational school of philosophy are argued to constitute valuable instruments to create a more hopeful attitude towards scientific dialogue. A final note is dedicated to the possible causes of the difficulties experienced in this area of reflection by contemporary humanist philosophy of science.
\end{abstract}




\section{Opsomming}

\section{Wanneer "paradigmas" verskil: wetenskaplike kommunikasie tussen skeptisisme en hoop in hedendaagse wetenskapsfilosofie}

Die eerste helfte van hierdie artikel skets die prentjie van hedendaagse humanistiese wetenskapsfilosofie wat toenemend verstrengel raak in 'n verlies aan selfvertroue oor die moontlikheid van substansiële kommunikasie tussen wetenskaplikes wat tot verskillende paradigmas of vooronderstellings behoort. Die tweede helfte bestaan uit die reaksies van 'n denkskool in die Christelike filosofie oor hierdie troostelose moontlikheid van 'n kommunikasiekrisis. Die bronne wat die reformatoriese filosofie aanwend, so word geredeneer, stel waardevolle instrumente beskikbaar om 'n hoopvoller houding tot die wetenskaplike dialoog te skep. 'n Finale afdeling brei uit oor die moontlike oorsake van die probleme wat hedendaagse wetenskapsfilosofie in hierdie denkarea ondervind.

\section{Introduction, problem statement and plan of action}

Humanist science started with considerable confidence in the possibility of communication among scientists. The works of Galileo often contained words like dialogo or discorso in their titles. ${ }^{1} \mathrm{Com}-$ munication was a precious possibility, often taken for granted both in philosophy and in science. It was one of the elements that granted credibility and legitimacy to science. How did it happen that even the possibility of scientific dialogue is questioned in the most recent philosophies of science? The latter can be considered as the main question of this article, together with a second one: What response could be offered, from a reformational point of view?

In the first part of this article (Sections 2-5), the gradual move towards skepticism concerning the possibility of scientific communication in contemporary philosophy of science is analysed. After a survey and description of this gradual process the possible resources are indicated that might help counteracting the present tendency towards relativism and pessimism. The philosophers analysed below are among those who offered the most relevant contributions, in the twentieth century, to the issue of the difficulties

1 See for example Galileo's Dialogue concerning the two chief world systems (1632) and Discourses on the new sciences (1638). Also in the title of his Sidereus nuncius the idea of communication is pre-eminent. 
of scientific dialogue among rival or competing schools in the various disciplinary fields.

The historical survey will start from Karl Popper, a philosopher who still maintained a considerable dose of optimism about the possibility of communication. This will provide a frame of reference against which the subsequent loss of confidence and the adoption of more pessimist and relativist views will become more apparent.

\section{Popper's relative optimism: communication must be possible}

The possibility of communication is mostly just taken for granted in Popper's work. If science is characterised by the proposal and critical evaluation of theories, it must be possible to communicate even among scientists of different persuasions. Of course he discussed the philosophies of several skeptics and irrationalists, but for Popper the negative consequences (for science) of their positions spoke for themselves.

On the other hand, Popper did not simply appropriate the positivist approach. The positivists had been looking for a kind of neutral language, a scientific language capable of eliminating the problems implicit in ordinary language (the latter in fact harboured nonscientific and "metaphysical" notions). Along the same line, they tended to identify verifiability with meaningfulness: linguistic statements that are non-verifiable do not have meaning. Popper, however, softened this hard-line: statements and theories can be non-scientific without necessarily being "meaningless, or nonsensical" (Popper, 1963:38-39).

It is only with the appearance of the works of Kuhn that the issue of incommunicability is faced with particular attention (and with a certain irritation) by Popper. He realises that here is a fundamental issue at stake, namely the "myth of the framework": the conviction that ideas can be debated only if certain basic assumptions are shared. Those who don't know or don't share the framework (he refers explicitly to Kuhn's paradigms), cannot be told about the theories and the facts generated by the framework. Popper has no doubt that such an approach is wrong. It is a form of relativism, actually the central bulwark of relativism (Popper, 1970:56).

To him, the whole issue boiled down to "transforming a difficulty into an impossibility" (Popper, 1970:56-57). Accepting the metaphor of translation, he asks: "Is it not true, that concepts and ideas can al- 
ways be translated into English, for example from Chinese or Hopi?" (Popper, 1970:56).

For Popper the gap between old and new theories is always relative. They are both footsteps in the way towards the approximation of truth. Also the gap between different generations of scientists and between rival "schools" remains relative. We are still capable of appreciating the theories of Newton, Galileo or Kepler. Their points of view can be fully understood.

\section{Realising the difficulties of communication: Michael Polanyi}

\subsection{The beginnings of Polanyi's career}

In Science faith and society (Polanyi, 1946), at the beginning of his career, Polanyi's attitude is quite close to Popper's. At that time Polanyi recognises the existence of several types of pre-scientific presuppositions and frameworks, but he highlights the fact that all scientists share those ideals and "premisses"; therefore the scientific communities show a high degree of consensus, and communication is never doubted. This attitude may be called the "conservative line" in Polanyi's philosophy (Coletto, 2007:74, footnote 53). Although this "line" continues to be presented in Personal knowledge (1958:205, 220,222 ), a second "line" of thought emerges quite clearly, a line that may be called "late-modern" (Coletto, 2007:74, footnote 54).

\subsection{Developing a "late-modern" line}

Following Polanyi's new approach one learns that the frameworks behind science can indeed be very different from each other. Instead of creating a common ground they often create controversies (see e.g. the controversies on fermentation or hypnotism) which are only apparently centered "on questions of factual evidence" (Polanyi, 1958:167).

The attitude is quite different from the one pervading Science faith and society. In this publication scientific thinking seems to be "locked up" within a certain framework. It is difficult to criticise our own frameworks because they all have an "epicyclical structure" supplying subsidiary explanations in difficult situations (Polanyi, 1958:291). According to Polanyi:

They have power to control our thought. They speak to us and convince us, and it is precisely in their power over our minds 
that we recognize their justification and their claim to universal acceptance. (Polanyi 1958, 265.)

And

No intelligence, however critical or original can operate outside such a fiduciary framework. (Polanyi, 1958:266.)

It is not possible, says Polanyi, to "prove" that our basic beliefs are reasonable, logical, or even acceptable. While the acceptance of a basic framework is the condition for having any knowledge, the framework itself can claim no self-evidence. Our basic beliefs are indubitable only in the sense that we believe them to be so. Our liberation from objectivism, according to Polanyi, is therefore to realise "that we can voice our ultimate convictions only from within our convictions" (Polanyi, 1958:267).

All this has immediate consequences for the possibility of scientific dialogue: the latter cannot be taken for granted anymore. According to Polanyi, formal operations relying on one framework of interpretation cannot demonstrate a proposition to a person who relies on another framework. Those who support a certain framework may not even succeed in being understood by the supporters of a different one, because "they must first teach them a new language" (Polanyi, 1958:151). Even the new "language" cannot be learned without a previous "decision" (by the audience) to accept the new hypothesis with sympathy. It is not just a matter of proving something scientifically or rationally.

Proponents of a new system can convince their audience only by first winning their sympathy for a doctrine they have not yet grasped. (...) Such an acceptance is (...) to this extent a conversion (Polanyi, 1958:151).

Such "conversions" divide the community of the scientists. Polanyi uses the language of religious experience when speaking about "disciples forming a school, the members of which are separated, for the time being, by a logical gap from those outside it. They think differently, speak a different language, live in a different world" (Polanyi, 1958:151-2; italics - RC).

\subsection{Polanyi's contribution: towards an assessment}

The relationship between the conservative and the late-modern line could probably be interpreted in many different ways. What could be considered as a series of contradictions by someone, can be re- 
garded as a dialectical unity by a more sympathetic reader. There can be a different answer to the question whether the two lines integrate each other, constitute an unresolved tension, or are even necessary to each other. In general, we can say that Polanyi provides a system which is more open than Popper's to the recognition of the difficulties of communication in science.

The philosophers to be analysed in the following sections welcomed especially the "second line" of Polanyi's philosophy in their own systems of thought. In the following section the contribution of Kuhn, who was a student of Polanyi and explored the important notion of incommensurability will be analysed, commencing with an assessment of his views of communication in The structure of scientific revolutions.

\section{Kuhn and incommensurability}

\subsection{Radical views in The structure of scientific revolutions ${ }^{2}$}

Compared to Polanyi, the possibility of communication is more problematic for Kuhn. In The structure, the prevailing paradigm provides on the one side the common ground for communication between adherents of the same paradigm. On the other side it is almost impossible (at least considering some of Kuhn's statements) to communicate with scientists who do not accept the same paradigm. Fortunately, according to Kuhn, only one paradigm can dominate a certain field of study in a certain period. This preserves a considerable degree of communication. The problem of communication rather arises in times of crisis, in transitional periods, when revolutions divide the scientific community between an old and a new generation.

For example, Kuhn (1970a:109) says that two scientific schools "will inevitably talk through each other when debating the relative merits of their respective paradigms". Looking at the history of science, one of the most striking examples of incommensurability, according to Kuhn, is the famous debate between the French chemists Proust and Berthollet. Proust claimed that all chemical reactions occurred in fixed proportions, while Berthollet stipulated that they did not. "Each collected impressive experimental evidence for his view. Never- 
theless (...) their debate was entirely inconclusive" (Kuhn 1970a: 132).

"During revolutions" says Kuhn (1970a:111), "scientists see new and different things (...). We may want to say that after a revolution scientists are responding to a different world. (...) what were ducks in the scientist's world before a revolution are rabbits afterwards". It is not only the perspective that changes, but the phenomenal world itself. Kuhn wishes to say that "after Copernicus astronomers lived in a different world" (Kuhn, 1970a:117), and after discovering oxygen "Lavoisier worked in a different world" (Kuhn, 1970a:118).

All this has important consequences for communication. "Before they can hope to communicate fully one group or the other must experience the conversion (...) a transition between (...) competing paradigms cannot be made a step at a time, forced by logic and neutral experience" (Kuhn, 1970a:150). How then are scientists brought to make this transposition? Kuhn simply answers that in fact "they are often not" (Kuhn, 1970a:150). He reminds the reader that copernicanism made few converts for almost a century after Copernicus' death. Such examples could be multiplied.

However, Kuhn's position contains many nuances and uncertainties. In the section that follows the "softening" of his radical views after The structure will be considered.

\subsection{The further development of Kuhn's views on scientific communication}

The "softening" of Kuhn's radical views on communication started already within The structure (cf. Kuhn, 1970a:129, 130, 150), especially in its Postscript. There scientists seem to be again able to listen to each other, at least in some sense. The stimuli that impinge upon them are the same, says Kuhn, and their "general neural apparatus" is the same. They share a history and in addition both their everyday experience and most of their scientific world and language are shared (Kuhn, 1970a:201).

In his further development Kuhn somehow narrowed and limited the concept of incommensurability. During the 1960s the incommensurability of two theories touched three aspects:

- differences in the phenomenal world;

- differences in the selection of problems and standards for their solution; and 
- differences of meaning.

At the end of the 1960s and beginning of 1970s the first two aspects were abandoned and incommensurability focused only on change of meaning (Kuhn, 1970b:267-268). In addition, Kuhn specified that his incommensurability thesis never implied that all concepts change in the transition to a new theory (e.g. Kuhn, 1970b:267, 269). Therefore two theories were now called incommensurable when there is no "language into which at least the empirical consequences of both can be translated without loss or change" (Kuhn, 1970b:266). This language would be a neutral observation language, but there is no such language.

Kuhn's further re-elaboration of the concept at the beginning of the 1980 s insists on the notion of translation. The argument concerning a neutral observation language disappears and untranslatability is involved in explaining incommensurability. "If two theories are incommensurable they must be stated in mutually untranslatable languages" (Kuhn, 2000:34). Here Kuhn has in mind translation in the narrow, technical sense (Kuhn, 2000:40) which consists in replacing single words (or groups of words) by words available in the target language. As this type of difficulties generate only "local incommensurability" Kuhn (2000:35-37) declares that "the claim that two theories are incommensurable is more modest than many of its critics have supposed" (Kuhn, 2000:36).

The "taming" of incommensurability requires the adoption of two other important ideas. The first one is that incommensurability does not imply incomparability (Kuhn, 1979:416). As a consequence (and this is the second idea) there remains a continuity between different traditions of normal science. The empirical potential of incommensurable theories can indeed be compared. Such theories have empirical interconnections. There must therefore remain a certain type of continuity even between incommensurable theories (Kuhn, 2000:36).

Kuhn gradually reduces and limits some of the radical claims he presented in The structure. This move seems to recover Polanyi's "conservative" line and is much appreciated by many recent commentators and contributors who feel much more at ease with Kuhn's 
latest conception of incommensurability and are determined to build on it. 3

\subsection{Kuhn between dialogue and incommensurability}

The latest development of Kuhn's thought shows that the gradual move towards relativism of contemporary philosophy of science is not simply a linear process. It is a process that knows pauses and even contradictions. Nevertheless, it should also be acknowledged that Kuhn takes a step further from where Polanyi was. In Kuhn's works incommensurability, according to Kuhn, becomes an established concept, entailing a potential threat to communication and to the legitimacy of science. This is certainly one of the reasons why Kuhn sometimes seems to hesitate. In order to maintain the credibility of science he tries to indicate a few possible antidotes to complete relativism. These hesitations, however, were abandoned by Feyerabend, who accepted the challenge of relativism and pluralism and even welcomed them as the basis of his philosophical system.

\section{Feyerabend and beyond: incommensurability, celebration and anxiety}

\subsection{Incommensurability, language and worldview}

It can be said that Kuhn and Feyerabend are very similar in their reflection on incommensurability, yet Feyerabend reaches a more radical position. The theme of incommensurability is introduced, in Against method, as something that anticipates the future radical character of philosophy of science. He admits that times are not completely mature to propose his anarchist approach, "that is liable to paralyse the brains of almost everyone" (Feyerabend, 1975:214).

According to Xiang Chen (1997:257-273) Kuhn's latest version of incommensurability is an attempt at reducing relativism. The same author argues that incommensurability can be only a "local phenomenon" and does not necessarily imply incomparability (Xiang Chen, 2003:962-974). On the contrary, says Xiang Chen (2002:1-21), even so-called incommensurable taxonomies can be rationally compared. Hoyningen-Huene (2002:61-83) points out that even Feyerabend, towards the end of his life, re-evaluated in more positive terms Kuhn's latest pronouncements on incommensurability. Sankey (1998:7-16) would even like to rescue Kuhn from anti-realism and to show that his latest version of incommensurability is compatible with a solid "scientific-realist framework". Newton-Smith (1981:102-107), a staunch defender of scientific rationality, remains a bit more ironic: in his view Kuhn started as a "revolutionary" and gradually became a "social democrat". 
On the other hand, one can already try to "anticipate the next stage". In fact, incommensurability is already here: we don't need to wait for the next scientific revolution. Kuhn may not realise it, but rival schools and paradigms have been proliferating and co-existing in all disciplines. 4 Incommensurability has to do with the "covert classifications" implicit in every language (Feyerabend, 1975:214).

Later Feyerabend provides another definition of incommensurability:

Let us call a discovery, or a statement, or an attitude incommensurable with (...) a theory, [or] framework if it suspends some of their universal principles. (Feyerabend, 1975:269.)

With these declarations, Feyerabend switches the focus from linguistics and translation to the worldviews, principles, beliefs and ontological convictions supporting these theories. The linguistic issues are not simply abandoned, but Feyerabend is convinced that statements and theories are dependent on some fundamental framework. When the basic assumptions of such a framework are denied ("suspended") by another framework or by statements or by a new theory, the two competing systems become incommensurable. Feyerabend dedicates a long section to establish the fact that incommensurability exists, perhaps feeling that Kuhn's work was not decisive on this point. His arguments refer to studies on children's perception (Feyerabend, 1975:227 ff.), but also to different styles in painting (Feyerabend, 1975:230 ff.). Analysing the Greek archaic style, Feyerabend outlines the basic view of the world underlying such painting. Without entering into the details, it can be said that, according to Feyerabend, the cosmology implied in these paintings is incompatible with our modern conception of the world and of man (Feyerabend, 1975:230).

When this happens in science, it is not possible to institute an experiment which will refute one of two theories (Feyerabend, 1975: 282). It is also not possible to find a neutral position from which it would be possible to compare for example the theory of relativity and classical physics (Feyerabend, 1975:275-76). It is an illusion even to suppose that incommensurable theories deal "with the same subject matter". This view is born from the wrong supposition that facts can be relatively independent from theories, but there are no

4 For example, in physics Feyerabend (1970:207-208) notices the presence of three competing schools after 1860 , which means at least three paradigms acting simultaneously on the scene of physical science. 
facts without theories. Therefore, incommensurable theories deal with totally different facts.

Does all this mean that communication between scientists, in such cases, is simply impossible? The answer must be positive, to a large extent, though according to Feyerabend it is still possible, for example, to refute incommensurable theories. It is not possible to do this by comparing their respective content. They can, however, be refuted by discovering their internal contradictions. Feyerabend admits that in the absence of commensurable alternatives "these confutations are quite weak, however" (Feyerabend, 1975:284), and "greatly reduced in strength" (Feyerabend, 1975:285). Although incommensurable theories are not totally immune to criticism the impression is that with Feyerabend the point is reached of a loss of communication. Feyerabend wanted to use the arguments of rationality in order to undermine rationality itself (Feyerabend, 1975: 33). The impression is that he also uses communication to prepare for a breakdown of (scientific) communication.

\subsection{Baudrillard: towards a postmodern implosion?}

With Feyerabend the possibility of incommunicability finally becomes a real challenge. This challenge is accepted, in postmodern times, with an attitude which is a mixture of celebration and anxiety. Baudrillard cannot avoid being concerned.

Though communication within scientific circles is not the primary focus of his criticism, it is included in his general analysis of representations, reproductions, hyper-reality, et cetera. In his view science and technology have caused the implosion of communication in general, exactly by exploiting its possibilities. His later works are especially dedicated to the media, but earlier he had conducted a thorough analysis of language and communication (Baudrillard, 1981).

According to Baudrillard (1984:129) in our epoch we have entered the "third order of simulacra", which is an order of simulation and is "controlled by the Code". Communication becomes mis-information and invades both public and private space. What is left is only "obscenity", in the sense that all is "transparency and immediate visibility when everything is exposed to the harsh and inexorable light of information and communication" (Baudrillard, 1984:130). This leads to "a state of terror, proper to the schizophrenic: too great proximity to everything" (Baudrillard, 1984:132). It leads especially to "the loss of the real" (Baudrillard, 1984:133). 
Communication was supposed to constitute the real, but exactly through its reproductions it has created the hyper-real, which is just a simulation without origin or relation to any reality. Technology and the media are certainly to be blamed for this, but the media at least share their responsibilities with misguided science and technology. Science has not only experienced the "internal" difficulties of communication, but has also prevented the possibility of true communication in contemporary society.

\subsection{Celebrating dissensus: Jean-Francois Lyotard}

Admittedly, not all voices are as pessimistic as Baudrillard's. Lyotard, for example, invites one to stop longing for a science in which consensus is one of the most important values. According to Lyotard, postmodern science should not seek to create consensus, but rather dissensus. In his view, Habermas' philosophy of consensus obtained through dialogue, $\mathbf{5}$ is based on the meta-narrative of emancipation (Lyotard, 1984:60). According to Lyotard (1984:65), Habermas is wrong in identifying emancipation and consensus. Consensus is only a particular state of discussion, not its end. Also Lyotard believes in the necessity of emancipation, but hopes to achieve it via the power of dissensus. Consensus can be the end of freedom and of debate. It is dissensus that allows the experience of liberation.

In Lyotard's view of science dialogue and communication do have a legitimate place, but it does not matter whether they are "effective", in any traditional sense. Actually, it is better if such dialogue doesn't reach any result, if consensus is avoided: this will keep the game going. Postmodern science, in his view, can open up new and exciting perspectives exactly by resisting consensus.

It is now time to consider the responses to the pessimistic views on the possibility of scientific communication provided by reformational philosophy. drift towards the loss of communication has been resisted. 


\section{Reformational responses}

\subsection{Dooyeweerd on "antithesis"}

With Dooyeweerd the problem of communication is not related only to the natural sciences but to the "humanities" as well, as the latter acquire full scientific status in his philosophy (as well as in more recent reformational scholars - cf. Strauss, 2001). Dooyeweerd is sometimes accused of having insisted too much on the impact of the "antithesis" in theoretical thinking, especially (but not exclusively) concerning the conflict between Christian and non-Christian scholarship (cf. Klapwijk, 1986:138-142). However, this antithesis in Dooyeweerd's (1959:70-72) view, was not supposed to constitute an obstacle to the dialogue between scientists of different persuasions. There is an equilibrium in his position, which is the result of a double acknowledgment in his epistemology. On the one hand he recognises the importance of ground motives, which indeed create a difference in the interpretation of creational data. This is true for philosophy as well as for the special sciences. On the other hand, Dooyeweerd acknowledges the reality of the order for creation (Dooyeweerd, 1959:72-73) constituting a common ground among scientists and thinkers.

In this respect it is interesting to mention that Dooyeweerd's second way of transcendental critique (Dooyeweerd, 1984, 1:22-57) begins from the structure of theoretical thought, which is a common ground for all thinkers. The issue of the "antithesis" is introduced only in the third and final "step" of his critique. It is also interesting to notice that Dooyeweerd's critics had strong differences of opinion in the evaluation of his idea of antithesis. For authors like Wolterstorff (1989:64$65)$ or Klapwijk (1986:141-143), Dooyeweerd's view of antithesis was too radical. In their opinion the dooyeweerdian idea of antithesis would divide the scientific community and hinder the cooperation among scholars. For others, however, the dooyeweerdian idea of antithesis was too weak.

The critiques by Cornelius Van Til (1971:99), for example centered on the impression that the theme of the religious ${ }^{6}$ antithesis was not

6 In the present context the adjective religious may create some perplexity. In reformational circles it does not refer only to Christianity or to the "classical" religions. It is possible to speak of the religious convictions (in the sense of the ultimate commitments) of humanists, atheists, positivists, Marxists and all those who "interpret" life in some way or the other (i.e. all human beings). According to Roy Clouser "a belief is religious provided that (1) it is a belief in something(s) or 
sufficiently emphasised by Dooyeweerd. According to the famous apologist of Westminster Seminary, Dooyeweerd should not have started his critique from supposedly neutral states of affairs (Van Til, 1971:99). Dooyeweerd's reply was that although he wanted to recognise the relevance of the religious antithesis, the states of affairs are founded in the cosmic law-order, not in any subjective consciousness, and therefore they are accessible to all thinkers, irrespective of their orientation (Dooyeweerd, 1971:80-81).

No matter what the convictions of the scientist are, according to Dooyeweerd she/he will have to deal with laws and structures that are not simply dependent on his/her views. By "states of affairs" Dooyeweerd did not indicate a reality simply disconnected from mankind, a reality that could, as such, provide the basis for scientific communication. His view of naive experience does not wish to imply a naive realistic conception of reality (Dooyeweerd, 1984, 3:34). This is even more the case with theoretical thought. ${ }^{7}$

Nevertheless, Dooyeweerd believes that when the creational data are neglected or interpreted incorrectly, theoretical thought itself will end up in antinomies and contradictions (Dooyeweerd, 1959:74). The views of the different scientists therefore, both in philosophy and special science, are not considered "incommensurable". Creation itself is the judge of our theories and it will continue to remain a normative source for all knowers (Dooyeweerd, 1959:72). It is precisely this intuition and acceptance of a created order which seems to be missing from humanist philosophy. This created order, on the other hand, seems to be accepted much more naturally by Christian systems of thought. 8 In the following section reference to some

other as divine or (2) a belief concerning how humans come to stand in proper relation to the divine". Divine, according to Clouser should be defined as "having the status of not depending on anything else" (Clouser, 1991:22-23).

7 On this point Dooyeweerd had important discussions with the Dutch philosopher C.A. van Peursen, who does not recognise the existence of states of affairs. He only recognises dynamic events and affairs that do not "stand", but are also constituted by the interaction with the knowing subject. (cf. Van Peursen, 1959).

8 The idea of a structural order is of course not exclusive to reformational circles. Troost (1994:2-16) demonstrates that the theme of a "creation order" has been present in Christian thinking from the patristic era up to the present. However, Troost (1994:8-16) also points out that in the Christian tradition this crucial idea has often been worked out especially from a theological perspective and has been shaped rather naively from a philosophical point of view. As a consequence, many types of alien influences (e.g. stoicism, neo-platonism) have been welcomed into various Christian conceptions of the creation order, thus 
other themes of Dooyeweerd's contribution will be made, while their connection to his Christian worldview will be pointed out.

\subsection{Dooyeweerd on scientific dialogue}

According to Dooyeweerd the religious antithesis does not magically divide the scientific community into two well-delimited groups. This antithesis cuts through the life of the Christian scientific community as well as through all other communities (Dooyeweerd 1984, 1:524). Scientists, who are Christians, sometimes adhere to unbiblical ground motives when it comes to science and apart from that, they are still under the influence of the fall. In addition, the religious ground motive is of course not the only reference point for scientific knowledge (Dooyeweerd, 1959:69). Creation is the God-given common denominator. Therefore the "states of affairs" can be discovered by all.

As a consequence, Dooyeweerd firmly believed in the possibility of communication and even cooperation between scientists of different persuasions. He looked forward to a "healthy and noble emulation" between all philosophical schools (Dooyeweerd, 1959:73; translation - RC). Christian scholarship is not bound to an oppositional attitude. The challenge for all schools of thought is to provide a reliable account of creational data, not jealously to defend their own views.

Dooyeweerd believed in the possibility of real dialogue, and his transcendental critique was intended to promote this dialogue. ${ }^{9} \mathrm{He}$ contended that it is exactly the "dogma" of the autonomy of theoretical thought that caused genuine dialogue to be impossible. The different schools, in his opinion, were not sufficiently aware of the deeper causes of their disagreements, which are often related to different ground motives. Once these motives are uncovered, it should be easier to come to a more open comparison of ideas and theories (Dooyeweerd, 1959:71).

There was for Dooyeweerd, a common call that was directed to all scholars and scientific communities. This view was a consequence

preventing a more original Christian contribution in both catholic and protestant thinking.

9 Of course there are, on this point, different evaluations of Dooyeweerd's endeavour. See for example the doctoral thesis of Conradie (1960) and the recent one by Choi (1999). 
of his Christian worldview. Notwithstanding the apostasy of humankind, God's cultural mandate to humanity is not cancelled. All scientists are exposed to the same risks and called to the same task. Even apostate thought contributes to the "fulfilment of the Divine plan" (Dooyeweerd, 1984, 1:119). In the present era it is not possible to gather the "faithful servants" (of the parable of the talents) in a separate "school" (Dooyeweerd, 1984, 1:524). It is the common task that imposes the necessity of humility and dialogue.

Admittedly, the different schools see things differently. This difference, however, does not cancel the reference to creational data. Dooyeweerd's classical example centers on the proposition $2+2=4$ (Dooyeweerd, 1959:72 ff.). Numerically speaking, the judgment $2+2=4$ corresponds to a state of affairs which is independent from every subjective theoretical view. Yet a difference of interpretation is manifested between the different currents of the philosophy of mathematics. The logicist tendency is thus opposed to the intuitionist, the formalist, the empiricist or to the sensualist tendency.

The conflict among interpretations is certainly real. However, according to Dooyeweerd, the structural order for the temporal horizon of experience, with all the states of affairs which are founded on it, is indubitably the same for every thinker, irrespective of the orientation of one's thought. Once they are discovered, the structural facts impose themselves on everybody and it would make no sense to try to deny them. All schools and currents of philosophy receive the common task of accounting for them in a philosophical way. These schools are inter-dependent, and must learn from each other. The philosophy of the cosmonomic idea, says Dooyeweerd, does not claim any privileged position among the other philosophical schools (Dooyeweerd, 1959:73).

It seems quite clear that the theme of a religious antithesis, as far as Dooyeweerd is concerned, does not cancel the possibility and necessity of dialogue. On the contrary, to discover this antithesis is the starting point to realise a meaningful dialogue. "Dialogue and antithesis", as the title of Choi's (1999) thesis reads, go hand in hand in Dooyeweerd's view.

\subsection{Different levels: implications for dialogue and framework- dependence of theories}

Reformational philosophy, according to Dooyeweerd, does not "attribute to its provisional and fallible results the infallible character of its religious starting point" (Dooyeweerd, 1959:73). This repre- 
sents another extremely important theme of the dooyeweerdian view. The only radical kind of antithesis is the religious antithesis (Dooyeweerd, 1984, 1:123). Other forms of antithesis are therefore relative. When speaking of incommensurability in science (and the same holds for antithesis) we must distinguish between the level of the deepest presuppositions and the level of the concrete theories. There is a definite difference between the two. In Dooyeweerd's words, the Biblical religious motive is believed to be infallible by the Christian, but his own scientific theories can only be regarded as provisional and fallible.

The point is quite important: by confusing or by not distinguishing properly the different levels, some philosophers of science tend to attribute the same degree of incommensurability to the starting points as well as to the theories. If the dialogue is not possible on the level of the deepest convictions, it cannot be possible at any other level, they would argue. There are of course differences between the different authors 10 but Feyerabend definitely shows a tendency to declare theories incommensurable because their prescientific frameworks are incompatible.

A sound distinction between different levels of presuppositions and scientific research (e.g. Duvenage, 1985:31 ff.) ${ }^{11}$ would allow for a more nuanced position. It is true that there is always a connection between presuppositional frameworks and concrete theories, a connection which is sometimes not immediately visible yet nevertheless real (Wolterstorff, 1976:79). The framework, however, does not completely determine the theories. The latter are not simply the

10 In some cases (see Kuhn's paradigm) the frameworks are constituted by elements that belong partially to the scientific and partially to the pre-scientific level. As a consequence the framework itself can be regarded as partially scientific. In this case, from a dooyeweerdian point of view, the hypothesis of incommensurability simply becomes more remote because complete "antithesis" is not plausible at the scientific level.

11 According to Duvenage's account of scholarship, three levels of scientific investigation should be recognised as different but connected to each other (Duvenage, 1985:31-36). He proposes the image of a spiral, in which we can distinguish three "levels" that are called: microfocus, mesofocus and macrofocus. In each level relevant "perspectives or visions" are found (Duvenage, 1985:33). "These visions cohere directly with the various levels which can be distinguished in the formation of science." (Duvenage, 1985:33.) In every level, Duvenage distinguishes both scientific and pre-scientific "perspectives". In this way he recognises both the different assumptions and the common engagement of all scholars with the debates and theories of a certain field of study. 
product of the presuppositions of the scientist (Van Riessen, 1992: 90). There is therefore a difference between the levels, and also a relative "independence" of theories from presuppositions of various depth and nature. This situation allows for a certain degree of communication.

Comparison and dialogue are thus possible not because of the existence of a neutral language, or because scholars can enter a neutral position outside their paradigms (positivism), or because the paradigms are rooted in a common ground (Polanyi's early writings), but because presuppositions are not decisive in a final sense and we live in a common (though not neutral) world. In the long run, the real world resists our reductions and distortions.

This entails another important implication for scientific dialogue: even our fundamental frameworks can be criticised and evaluated. It might be impossible to compare two religious motives in abstract. Even in this case, however, according to Dooyeweerd (e.g. 1959) their influence on theoretical thought can be observed and we can criticise each other. When one realise, for example, that one's philosophy and science are full of absolutisations, of reductionism and of consequent antinomies, one has a clue about the problematic nature of one's deepest presuppositions. And this can certainly become a relevant topic for a dialogue among proponents of rival frameworks and theories.

Having argued in favour of a relative dependence of theories on frameworks and worldviews, in the following section the thesis will be defended that even concepts and statements are only relatively dependent on the theories in which they appear.

\subsection{Stafleu: relative theory dependence of concepts and statements}

Authors like Kuhn, Hanson and Feyerabend have criticised the empiricist position and have stressed theory-dependence of concepts and statements. In their philosophies, such theory-dependence is stressed to such an extent that the meaning of concepts and the truth of statements are completely determined by the theory in which they function. This implies that, in principle, competing theories cannot be compared. This constitutes a powerful argument in favour of incommensurability. If the basic assumptions of complete theorydependence can be shown to be flawed, there is obviously hope that incommensurability may be rejected and the dialogue between proponents of different views may be placed on more solid ground. 
In this context one could refer to Stafleu's (e.g. 1987:26-29) contribution, because he defends the idea of a relative theory-dependence of concepts and statements. Finding his starting point in Dooyeweerd's theory of modalities, he suggests a position that "takes a middle course between two more extreme views, logicalempiricism, and historical relativism" (Stafleu, 1987:28). First he clarifies the term intension (= meaning) referred to concepts, and the term extension (the number of entities belonging to the class). After a short discussion of the concept planet he concludes that "the extension of a concept can be changed without changing its intension"12 (Stafleu, 1987:26). The consequences drawn by Stafleu are far-reaching:

Hence the meaning of a concept is partly determined by its theoretical context; it is theory dependent. But its meaning also has a certain autonomy with respect to the theory. A similar view can be held with respect to statements. (Stafleu, 1987:2728.)

In order to support the relative theory-dependence of concepts and statements, Stafleu proposes a second argument, which takes into account the theory of modal aspects. Theories, says Stafleu (1987: 29) have a typical kinematic aspect, deduction being the logical movement from one statement to another. Similarly, statements have a typical spatial aspect, because they are dominated by the idea of connection. The structure of a concept refers to the logical unity and diversity, in other words to the numerical aspect of experience.

Supposing the numerical, spatial, kinematic and logical aspects to be mutually irreducible, we now understand both why concepts and statements are theory dependent, and why they have nevertheless an irreducible autonomy. In this structural interlacement the meaning of concepts and the truth of statements are both relativized and opened up, if they start to function in a theory. (Stafleu, 1987:29.)

12 On this specific point it is interesting to compare Stafleu's approach with Kuhn's. Kuhn (2000:15 ff.) analyses the sentence "in the Ptolemaic system planets revolve around the earth; in the Copernican they revolve about the sun". He concludes that "the sentence is incoherent. The first occurrence of the term planet is Ptolemaic, the second Copernican, and the two attach to nature differently. For no univocal reading of the term planet is the compound sentence true" (Kuhn, 2000:15). 
The target of Stafleu's arguments is the notion of incommensurability. He wants to propose a middle course between two more extreme views, namely logical empiricism, and historical relativism.13 One of the fundamental assumptions of logical empiricism was the existence of observation statements and concepts independent of any theory (Suppe, 1974:14). These were called observation statements and observational (or empirical) concepts. The empiricists strongly relied on observation and assumed the possibility of finding purely empirical protocol statements, independent of any theory. For Stafleu, however, observations cannot take place outside the context of one's expectations, frameworks and presuppositions in general. More in particular, for the observations performed in laboratories, sophisticated instruments are used that are often developed according to quite elaborated theories.

The agreement on the fact that observations cannot be made apart from any theoretical context, however, should not blind one to the fact that observational results may be quite independent of some theories. As an example, Stafleu (1987:29) mentions the occasional backward motion of the planets, which played a considerable role in Copernicus' heliocentric theory and was never disputed by any astronomer, copernican or not.

\section{Conclusive remarks}

It is time to come to a conclusion. The growing distrust concerning the possibility of true scientific communication, culminating in the theme of incommensurability have been explored. Also, the allegations that it might not be possible to compare certain standpoints or to entertain a dialogue between academic schools holding to different presuppositions, have been explored. In the second part of the article a few reformational responses have been sketched in order to provide an alternative to the dilemmas encountered within recent humanist philosophy of science.

Although the deeper reasons for the different approaches were not explored, a hypothesis can briefly be proposed, which implies a call for further research on this topic. The ideal of the free creativity of the knowing subject (which gradually gained the primacy during the twentieth century) constitutes one of the two "poles" of the humanist ground motive. The nature-pole, inspiring positivism and leading to

13 With this definition he refers e.g. to some of the works of Kuhn, Feyerabend, Hesse and others (Stafleu, 1987:28, footnote 34). 
the idea of "neutral" facts, constitutes the dialectical rival of the freedom-pole (Dooyeweerd, 1984, 1:190-495). The freedom-pole points towards the existence of totally different frameworks of thought, languages, and finally totally different worlds. The common ground of a creational order is then rejected in favour of the recognition of a plurality of language games, frameworks and premises.

The problem is that, in this perspective, the possibility of communication becomes increasingly more remote. Nowadays humanist thinking is attempting to reach a more "moderate" position concerning the possibility of communication (cf. footnote 3 ). This goal, however, can only be achieved either by attempting a synthesis between the two conflicting poles of the humanist ground motive, or by suppressing the "claims" of the freedom-pole altogether. As both alternatives are quite unlikely to lead to satisfactory solutions, the proposals of the reformational school should be taken into account as possible alternatives.

\section{List of references}

BAUDRILLARD, J. 1981. For a critique of the political economy of the sign. St. Louis: Telos.

BAUDRILLARD, J. 1984. The ecstasy of communication. (In Foster, H., ed. Postmodern culture. London: Pluto. p. 126-134.)

CHOI, W.Y. 1999. Dialogue and antithesis: a philosophical study on the significance of Herman Dooyeweerd's transcendental critique. Potchefstroom: PU for CHE. (Ph.D. thesis.)

CLOUSER, R.A. 1991. The myth of religious neutrality: an essay on the hidden role of religious belief in theories. Notre Dame: University of Notre Dame Press.

COLETTO, R. 2007. The legitimacy crisis of science in late-modern philosophy: towards a reformational response. Potchefstroom: North-West University. (Ph.D. thesis.)

CONRADIE, A.L. 1960 The neo-calvinistic concept of philosophy: a study in the problem of philosophic communication. Pietermaritzburg: Natal University Press. (Ph.D. thesis.)

DOOYEWEERD, H. 1959. Cinq conferences. La revue reformee, 10(3):3-76.

DOOYEWEERD, H. 1971. Cornelius Van Til and the transcendental critique of theoretical thought. (In Gehaan, E.R., ed. Jerusalem and Athens. Nutley: Presbyterian \& Reformed Publications. p. 74-89.)

DOOYEWEERD, H. 1984. A new critique of theoretical thought: 4 volumes. Jordan Station: Paideia.

DUVENAGE, B. 1985. Christian scholarship as Word-bound scholarship. Potchefstroom: PU for CHE.

FEYERABEND, P.K. 1970. Consolation for the specialist. (In Lakatos, I. \& Musgrave, A., eds. Criticism and the growth of knowledge. Cambridge: Cambridge University Press. p. 197-230.) 
FEYERABEND, P.K. 1975. Against method: outline of an anarchistic theory of knowledge. London: New Left Books.

HABERMAS, J. 1984. Modernity: an incomplete project. (In Foster, H., ed. Postmodern culture. London: Pluto. p. 3-16.)

HOYNINGEN-HUENE, P. 2002. Paul Feyerabend and Thomas Kuhn. Journal for general philosophy of science, 33(1):61-83.

KLAPWIJK, J. 1986. Antithesis, synthesis and the idea of transformational philosophy. Philosophia reformata, 51(1-2):138-152.

KUHN, T.S. 1970a. The structure of scientific revolutions. Chicago: University of Chicago Press.

KUHN, T.S. 1970b. Reflections on my critics. (In Lakatos, I. \& Musgrave, A., eds. Criticism and the growth of knowledge. Cambridge: Cambridge University Press. p. 231-277.)

KUHN, T.S. 1979. Metaphor in science. (In Ortony A., ed. Metaphor and thought. Cambridge: Cambridge University Press. p. 409-419.)

KUHN, T.S. 2000. The road since structure: philosophical essays 1970-1993. Chicago: University of Chicago Press.

LYOTARD, J.-F. 1984. The postmodern condition: a report on knowledge. Manchester: Manchester University Press.

NEWTON-SMITH, W.H. 1981. The rationality of science. London: Routledge \& Kegan Paul.

PLANCK, M. 1949. Scientific autobiography and other papers. New York: Philosophical Library.

POLANYI, M. 1946. Science faith and society. Chicago: University of Chicago Press.

POLANYI, M. 1958. Personal knowledge: towards a post-critical philosophy. London: Routledge \& Kegan Paul.

POPPER, K.R. 1963. Conjectures and refutations: the growth of scientific knowledge. London: Routledge \& Kegan Paul.

POPPER, K.R. 1970. Normal science and its dangers. (In Lakatos, I. \& Musgrave, A., eds. Criticism and the growth of knowledge. Cambridge: Cambridge University Press. p. 51-58.)

SANKEY, H. 1998. Taxonomic incommensurability. International studies in the philosophy of science, 12(1):7-16.

STAFLEU, M.D. 1987. Theories at work: on the structure and functioning of theories in science, in particular during the copernican revolution. Lanham: University Press of America.

STRAUSS, D.F.M. 2001. Does it make sense to distinguish between the natural sciences and the humanities? Tydskrif vir Christelike wetenskap, 37(12):25-36.

SUPPE, F. 1974. The structure of scientific theories. Urbana: University of Illinois Press.

TROOST, A. 1994. The idea of creation order in Christian thought. (In Van der Walt, B.J., ed. God's order for creation. Potchefstroom: Institute for Reformational Studies. p. 2-16.)

VAN PEURSEN, C.A. 1959. Enkele critische vragen in margine bij $A$ new critique of theoretical thought. Philosophia reformata, 24(2):160-168.

VAN RIESSEN, H. 1992. Science in the light of the relation between thinking and believing. Tydskrif vir Christelike wetenskap, 28(1):27-95.

VAN TIL, C. 1971. Response by C. van Til. (In Gehaan, E.R., ed. Jerusalem and Athens. Nutley: Presbyterian and Reformed Publications. p. 89-127.) 
WOLTERSTORFF, N.P. 1976. Reason within the bounds of religion. Grand Rapids: Eerdmans.

WOLTERSTORFF, N.P. 1989. On Christian learning. (In Marshall, P.A., Griffioen, S. \& Mouw, R.J., eds. Stained glass: worldviews and social science. Lanham: University Press of America. p. 56-80.)

XIANG CHEN. 1997. Thomas Kuhn's latest notion of incommensurability. Journal for general philosophy of science, 28(2):257-273.

XIANG CHEN. 2002. The "platforms" for comparing incommensurable taxonomies: a cognitive-historical analysis. Journal for general philosophy of science, 33(1):1-21.

XIANG CHEN. 2003. Object and event concepts: a cognitive mechanism of incommensurability. Philosophy of science, 70(5):962-974.

\section{Key concepts:}

antithesis, reformational view of

concepts and statements, theory-dependence of

framework-dependence of theories

incommensurability

scientific communication

Kernbegrippe:

antitese, reformatoriese siening van

konsepte en stellings, teorie-afhanklikheid van

onvergelykbaarheid

raamwerk-afhanklikheid van teorieë

wetenskaplike kommunikasie 
